\title{
Short communication: Noninvasive indicators to identify lactating dairy cows with a greater risk of subacute rumen acidosis
}

\author{
X. Gao and M. Oba ${ }^{1}$ \\ Department of Agricultural, Food and Nutritional Science, University of Alberta, Edmonton, AB, Canada T6G 2P5
}

\begin{abstract}
The objective of the current study was to evaluate if milk urea nitrogen (MUN) and milk fat content could be used as the noninvasive indicator to identify cows with greater or lower risk of subacute ruminal acidosis (SARA). Our hypothesis was that cows with lower MUN and milk fat content would have greater risk of SARA, whereas cows with higher MUN and milk fat content would have lower risk of SARA. In the screening study, 35 late-lactating Holstein cows (DIM $=250$ $\pm 71.1 ; \mathrm{BW}=601 \pm 45.4 \mathrm{~kg}$ ) were fed a high-grain diet containing $35 \%$ forage and $65 \%$ concentrate mix ad libitum for $21 \mathrm{~d}$. Concentration of MUN ranged from 5.7 to $13.9 \mathrm{mg} / \mathrm{dL}$ among the 35 cows, and the average milk fat content was $3.5 \%$. Then, 5 cows with highest MUN concentrations with milk fat higher than $3.5 \%$ were selected as animals that presumably have low risk of SARA, and 5 cows with lowest MUN concentrations with milk fat less than $3.5 \%$ were selected as animals that presumably have high risk of SARA. These 10 animals were ruminally cannulated during the subsequent dry period. As 1 low-risk cow was culled due to fatty liver, 9 animals $(\mathrm{DIM}=122 \pm 33.2 ; \mathrm{BW}=615$ $\pm 49.1 \mathrm{~kg}$ ) were used in the subsequent study in the following lactation. All cows were fed a high-grain diet consisting of $35 \%$ forage and $65 \%$ concentrate mix ad libitum for $21 \mathrm{~d}$. Ruminal $\mathrm{pH}$ was measured every 30 $\mathrm{s}$ for $72 \mathrm{~h}$. Minimum (5.75 vs. 5.30) and mean ruminal $\mathrm{pH}$ (6.35 vs. 6.04) was higher for low- compared with high-risk animals. In addition, duration of rumen $\mathrm{pH}$ below 5.8 was shorter in low-risk animals ( 52.5 vs. 395 $\mathrm{min} / \mathrm{d}$ ). These results suggested that MUN and milk fat content in late-lactating cows fed a high-grain diet may be used to identify cows that have higher or lower risk of SARA.
\end{abstract}

Key words: subacute ruminal acidosis, milk urea nitrogen, milk fat

\footnotetext{
Received February 11, 2015.

Accepted April 9, 2015.

${ }^{1}$ Corresponding author: moba@ualberta.ca
}

\section{Short Communication}

Subacute ruminal acidosis is a metabolic disorder particularly prevalent in high-producing dairy herds, mainly caused by feeding excessively fermentable diets. Better understanding of diet formulation strategies could reduce the incidence of SARA, but some cows in a herd still experience SARA even if these strategies are implemented. Previous studies indicated that huge variations exist in the extent of severity of SARA among beef steers (Brown et al., 2000; Schlau et al., 2012), primiparous dry cows (Penner et al., 2007), sheep (Penner et al., 2009), and lactating dairy cows (Gao and Oba, 2014) fed identical diets. Although the reason is not fully understood, these variations could be due to differences in acid production in the rumen or acid removal from the rumen by absorption through rumen epithelial cells, neutralization with buffers, and passage to lower digestive tracts (Penner et al., 2009). This is a concern on dairy farms because the rations are often formulated for a group of animals, and the susceptible cows may experience SARA whereas the other animals do not. Therefore, identifying cows that have higher or lower risk of SARA and adjusting nutritional management accordingly may reduce this nutritional disorder. However, it is not practical to measure rumen $\mathrm{pH}$ of all cows on commercial dairies, and it is necessary to determine a noninvasive indicator to identify cows with high and low risk of SARA. It has been suggested that milk fat depression is commonly associated with SARA (Oetzel, 2003; Stone, 2004). However, in our previous study (Gao and Oba, 2014), we found that cows with higher risk of SARA had lower MUN compared with those with lower risk of SARA, although there was no difference in milk fat concentration. Therefore, the objective of the current study was to evaluate if MUN and milk fat content could be used as the noninvasive indicator to identify cows with high and low risk of SARA.

All experimental procedures used in our study were approved by the University of Alberta Animal Care and Use Committee for Livestock and conducted according to the guidelines of the Canadian Council of Animal Care (Ottawa, Ontario, Canada). 
Thirty-five late-lactating Holstein cows $(\mathrm{DIM}=250$ $\pm 71.1 ; \mathrm{BW}=601 \pm 45.4 \mathrm{~kg}$; mean $\pm \mathrm{SD}$ ) were used in the first study (screening study). Their average milk yield was $28.8 \mathrm{~kg} / \mathrm{d}$. Cows were fed a high-grain diet consisting of $35 \%$ forage and $65 \%$ concentrates ad libitum for $21 \mathrm{~d}$ to induce SARA (Table 1). Cows were housed individually in tie-stalls bedded with wood shavings, fed the experimental diet as a TMR once daily at 0800 $\mathrm{h}$, and had free access to water. Feed was offered at 105 to $110 \%$ of actual feed intake of the previous day. The weight of feed offered and refused was recorded daily. The DM concentration of barley silage was determined twice weekly and diet formulation was adjusted if necessary. Cows were weighed after the morning milking on 2 consecutive days immediately before the start of experiment. Cows were milked twice daily at 0400 and $1500 \mathrm{~h}$. After an 18-d diet adaptation period, milk samples were collected for 3 consecutive days. Milk was sampled from both morning and afternoon milkings on d 19, 20, and 21. Milk samples were analyzed for milk fat, CP, lactose, and MUN by infrared spectroscopy (AOAC International, 2002; method 972.16; MilkoScan 605, Foss North America, Brampton, ON, Canada) at the Alberta Central Milk Testing Laboratory (Edmonton, AB, Canada). Concentration of MUN and milk fat ranged from 5.7 to $13.9 \mathrm{mg} / \mathrm{dL}$ and from 2.32 to $4.84 \%$, respectively. As the average milk fat content was $3.5 \%, 5$ cows with the highest MUN concentrations with milk fat content higher than $3.5 \%$ were selected as animals that presumably have low risk of SARA (LS), and 5 cows with the lowest MUN concentrations with milk fat less than $3.5 \%$ were selected as animals that presumably have high risk of SARA (HS; Figure 1). Concentrations of milk fat (4.10 vs. $2.95 \% ; P<0.01)$ and MUN (12.9 vs. $8.03 \mathrm{mg} / \mathrm{dL} ; P<0.01)$ were higher for LS compared with HS cows. These 10 animals were ruminally cannulated during the subsequent dry period.

The second study (rumen pH-monitoring study) was conducted during the following mid-lactation. As 1 LS cow was culled due to fatty liver, 5 HS and 4 LS ruminally cannulated cows $(\mathrm{DIM}=122 \pm 33.2 ; \mathrm{BW}=615$ $\pm 49.1 \mathrm{~kg}$; mean $\pm \mathrm{SD}$ ) were used. All cows were fed a high-grain diet in TMR consisting of $35 \%$ forage and $65 \%$ concentrates ad libitum for $21 \mathrm{~d}$ to induce SARA (Table 1). The daily cow management was similar to the first study, described previously. After $18 \mathrm{~d}$ of diet adaptation, ruminal $\mathrm{pH}$ was measured in the ventral sac every $30 \mathrm{~s}$ continuously for $72 \mathrm{~h}$ (d 19-21) using the $\mathrm{pH}$ measurement system evaluated by Penner et al. (2006). Minimum, mean, and maximum pH, as well as duration and area below $\mathrm{pH} 5.8$ were determined for each cow daily and averaged over the 3 -d period. These data were used to determine acidosis index (area under pH 5.8 divided by DMI; Penner et al., 2009) to assess the severity of SARA normalized for a feed consumption level. Milk samples were collected from both morning and afternoon milkings on d 19, 20, and 21 of the study as well. Milk samples were analyzed for milk fat, protein, and MUN as described above.

All response variables were evaluated for the group effect using the PROC TTEST procedure of SAS (version 9.2, SAS Institute Inc., Cary, NC). Significance was declared at $P<0.05$, and tendency was declared at $0.05<P<0.10$.

In the rumen pH-monitoring study, no difference in DIM, BW, and DMI was noted between LS and HS animals $(P>0.10$; Table 2$)$. However, the minimum $(5.75$ vs. $5.30 ; P=0.02)$ and mean ruminal $\mathrm{pH}(6.35$ vs. 6.04 ; $P=0.02)$ was higher for LS animals compared with HS animals. In addition, duration of rumen $\mathrm{pH}$ below 5.8 was shorter in LS animals $(52.5$ vs. $395 \mathrm{~min} / \mathrm{d} ; P$ $=0.04)$. Although huge numerical differences were observed, area of rumen $\mathrm{pH}$ below 5.8 and acidosis index were not different between the groups, which is possibly due to relatively low number of animals in the study; we had a $25 \%$ chance to detect the differences in area

Table 1. Ingredient and nutrient composition of the experimental diets

\begin{tabular}{lcc}
\hline Item & $\begin{array}{c}\text { Screening } \\
\text { study }\end{array}$ & $\begin{array}{c}\text { Rumen } \mathrm{pH} \\
\text { monitoring study }\end{array}$ \\
\hline Ingredient, \% DM & & \\
Barley silage & $35.6^{1}$ & $35.0^{2}$ \\
Barley grain, rolled & 23.5 & 23.6 \\
Corn grain, rolled & 22.2 & 17.5 \\
Canola meal & 5.13 & 13.5 \\
Corn gluten meal & 4.35 & 4.36 \\
Amino plus & 5.26 & - \\
Beet pulp & - & 2.73 \\
Vegetable oil & 1.52 & 0.84 \\
Sucrose & 0.57 & - \\
Mineral and vitamin mix & $1.87^{3}$ & $2.40^{4}$ \\
Nutrient composition & & \\
DM & 57.3 & 54.4 \\
Ash, \% of DM & 7.15 & 6.95 \\
CP, \% of DM & 16.5 & 16.4 \\
NDF, \% of DM & 25.8 & 28.2 \\
Starch, \% of DM & 32.0 & 29.0 \\
Ether extract, \% of DM & 4.56 & 4.10 \\
NFC, \% of DM & 46.1 & 46.6 \\
Forage NDF, \% of DM & 16.7 & 16.2 \\
\hline
\end{tabular}

${ }^{1} 31.0 \% \mathrm{DM}, 12.4 \% \mathrm{CP}, 48.1 \% \mathrm{NDF}$, and $12.1 \%$ starch.

${ }^{2} 32.1 \%$ DM, $11.3 \% \mathrm{CP}, 51.7 \% \mathrm{NDF}$, and $11.6 \%$ starch.

${ }^{3}$ Contained $11.6 \% \mathrm{Ca}, 3.4 \% \mathrm{P}, 18.0 \% \mathrm{Na}, 27.8 \% \mathrm{Cl}, 6.8 \% \mathrm{Mg}, 0.24 \%$ $\mathrm{S}, 0.04 \% \mathrm{~K}, 2,447 \mathrm{mg} / \mathrm{kg}$ of Fe, $551 \mathrm{mg} / \mathrm{kg}$ of $\mathrm{Cu}, 1,054 \mathrm{mg} / \mathrm{kg}$ of Mn, $13 \mathrm{mg} / \mathrm{kg}$ of Co, $842 \mathrm{mg} / \mathrm{kg}$ of Zn, $8.23 \mathrm{mg} / \mathrm{kg}$ of Se, $24.7 \mathrm{mg} / \mathrm{kg}$ of I, $504 \mathrm{kIU} / \mathrm{kg}$ of vitamin A, $51.3 \mathrm{kIU} / \mathrm{kg}$ of vitamin D, 1,651 IU $/ \mathrm{kg}$ of vitamin E.

${ }^{4}$ Contained $15.3 \%$ Ca, $2.8 \%$ P, $12.4 \%$ Na, $25.0 \%$ Cl, $5.4 \%$ Mg, $0.29 \%$ $\mathrm{S}, 6.5 \% \mathrm{~K}, 3,270 \mathrm{mg} / \mathrm{kg}$ of Fe, $665 \mathrm{mg} / \mathrm{kg}$ of $\mathrm{Cu}, 1,246 \mathrm{mg} / \mathrm{kg}$ of Mn, $14.9 \mathrm{mg} / \mathrm{kg}$ of Co, $1,010 \mathrm{mg} / \mathrm{kg}$ of Zn, $9.95 \mathrm{mg} / \mathrm{kg}$ of Se, $32.4 \mathrm{mg} / \mathrm{kg}$ of I, $510 \mathrm{kIU} / \mathrm{kg}$ of vitamin A, $51.7 \mathrm{kIU} / \mathrm{kg}$ of vitamin D, 1,668 IU/ $\mathrm{kg}$ of vitamin $\mathrm{E}$. 


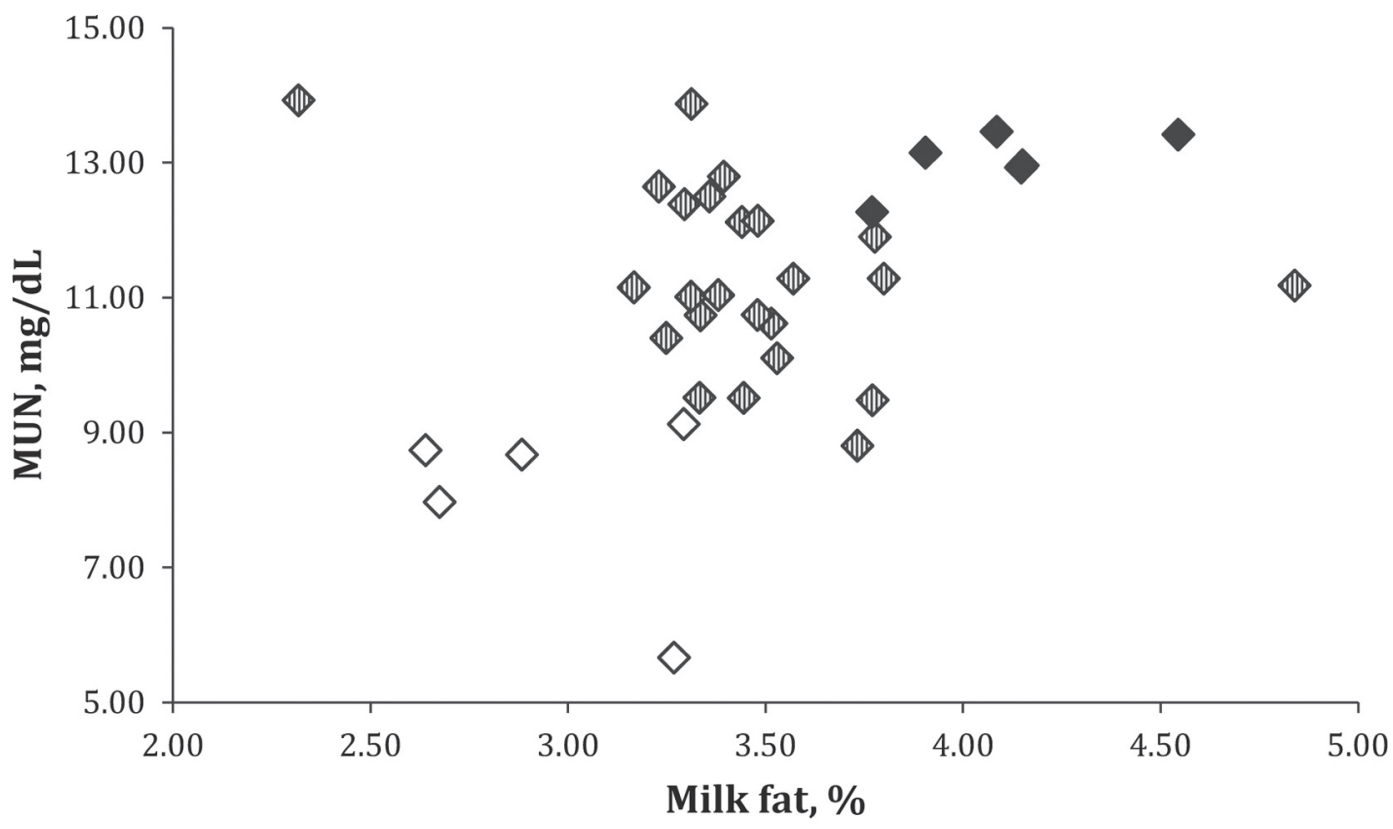

Figure 1. Variation of MUN and milk fat content among 35 animals in the screening study; cows with a presumably high risk of SARA (white diamond) and cows with presumably low risk of SARA (black diamond). Striped diamonds represent the other 25 cows used in the screening study that were not selected for the rumen pH-monitoring study.

below $\mathrm{pH} 5.8$ and acidosis index between the groups according to a power analysis. In the current study, LS cows identified in the screening study had higher rumen $\mathrm{pH}$ than the HS cows in the rumen $\mathrm{pH}$-monitoring study, which was conducted in the subsequent lactation; but it is important to note that the risk of SARA can change during the life of cows. Dohme et al. (2008) has shown that the severity of acidosis increased for cows with repeated acidosis challenges, which suggests that feeding history can affect SARA risk within the same cows.
Milk yield was lower for LS cows compared with HS cows in the rumen pH-monitoring study (33.8 vs. 40.7 $\mathrm{kg} / \mathrm{d} ; P=0.05)$. However, no difference was observed in milk yield between LS and HS cows in our previous study (Gao and Oba, 2014). Therefore, we cannot suggest a relationship between milk yield and risk of SARA. In addition, no differences in yields or concentration of milk components were seen between LS and HS groups in the rumen $\mathrm{pH}$-monitoring study.

Milk fat depression is commonly associated with SARA (Oetzel, 2003; Stone, 2004). Low rumen pH

Table 2. Comparison of DIM, BW, DMI, and $\mathrm{pH}$ measurements between $\mathrm{LS}^{1}$ and $\mathrm{HS}^{2}$ cows in the rumen $\mathrm{pH}$ monitoring study

\begin{tabular}{|c|c|c|c|c|c|}
\hline \multirow[b]{2}{*}{ Variable } & \multicolumn{2}{|c|}{$\mathrm{LS}(\mathrm{n}=4)$} & \multicolumn{2}{|c|}{$\mathrm{HS}(\mathrm{n}=5)$} & \multirow[b]{2}{*}{$P$-value } \\
\hline & LSM & $\mathrm{SE}$ & LSM & SE & \\
\hline DIM & 116 & 17.5 & 123 & 15.7 & 0.66 \\
\hline $\mathrm{BW}, \mathrm{kg}$ & 637 & 23.9 & 598 & 21.4 & 0.27 \\
\hline DMI, kg & 26.7 & 1.25 & 26.5 & 1.12 & 0.90 \\
\hline \multicolumn{6}{|l|}{ Ruminal pH } \\
\hline Nadir & 5.75 & 0.11 & 5.30 & 0.09 & 0.02 \\
\hline Mean & 6.35 & 0.07 & 6.04 & 0.06 & 0.01 \\
\hline Maximum & 6.93 & 0.07 & 6.81 & 0.07 & 0.27 \\
\hline Duration $\mathrm{pH}<5.8$, min & 52.5 & 103 & 395 & 91.9 & 0.04 \\
\hline Area $\mathrm{pH}<5.8, \mathrm{pH} \times \min$ & 7.68 & 45.8 & 107 & 41.0 & 0.15 \\
\hline Acidosis index, $\mathrm{pH} \times \mathrm{min} / \mathrm{kg}$ & 0.29 & 1.83 & 4.26 & 1.64 & 0.15 \\
\hline
\end{tabular}

${ }^{1} \mathrm{LS}=$ cows with highest MUN concentrations with milk fat higher than $3.5 \%$ in the screening study; selected as animals that presumably have low risk of SARA.

${ }^{2} \mathrm{HS}=$ cows with lowest MUN concentrations with milk fat less than $3.5 \%$ in the screening study; selected as animals that presumably have high risk of SARA. 
likely causes alternative pathways of ruminal FA biohydrogenation in the rumen, and these specific biohydrogenation intermediates are subsequently taken up by the mammary gland to induce substantial decreases in milk fat content and yield (Bauman and Griinari, 2003). However, milk fat content did not differ between LS and HS cows in the rumen pH-monitoring study, which was not consistent with the screening study but is consistent with our previous study (Gao and Oba, 2014). In the previous study, we observed a large numerical difference in milk fat concentration between the 2 groups (3.22 vs. $2.73 \%$ ), but we could not detect this with statistical significance due to a substantial variation within groups $(\mathrm{SE}=0.33)$. Similarly, a large numerical difference in milk fat concentration was observed between the 2 groups (3.61 vs. 3.08\%) in the current rumen $\mathrm{pH}$-monitoring study, and the difference was not significant due to the substantial variation within groups ( $\mathrm{SE}=0.29)$. Oetzel (2007) also indicated that the relationship between SARA and milk fat depression is inconsistent, and that many cows and herds with substantially depressed ruminal $\mathrm{pH}$ could have no milk fat depression. Therefore, these studies suggested that other unidentified factors, besides rumen $\mathrm{pH}$, affected milk fat content, and milk fat content alone was not a sensitive indicator to identify cows with high or low risk of SARA.

The current results suggest that MUN content along with milk fat content can be useful indicators to identify cows with high or low risk of SARA. Concentration of MUN is a good predictor of urinary $\mathrm{N}$ excretion and the efficiency of protein utilization in dairy cows (Gustafsson and Palmquist, 1993; Kohn et al., 2002). It has been suggested that MUN can be influenced by nutritional factors, such as the ratio of dietary $\mathrm{CP}$ to energy (Oltner and Wiktorsson, 1983), the extent of CP degradation in the rumen (Roseler et al., 1993), the amount of ammonia in excess of microbial $\mathrm{N}$ requirements (Hof et al., 1997), and protein or energy intake relating to feeding requirements (Carlsson and Pehrson, 1994). In addition, Abdoun et al. (2006) suggested that carbohydrate fermentation in the rumen can alter the permeability of the epithelial cell and the extent of urea recycled back to the rumen, which could affect MUN concentration; the more urea- $\mathrm{N}$ is recycled back to the rumen, the less would be excreted in urine and milk. Besides the nutritional factors, MUN is also affected by breed, DIM, parity, season, milking frequency, level of production, and sampling time (morning vs. afternoon milking) (Carlsson et al., 1995; Broderick and Clayton, 1997), as well as unidentified animal factors (Wattiaux et al., 2005; Cyriac et al., 2008; Rius et al., 2010).
Significant differences in MUN concentration were observed between cows that differ in SARA risk in our previous study (Gao and Oba, 2014), as well as in the screening study in which late-lactation cows were used. Greater MUN concentration for LS cows may be attributed to lower OM fermentation in the rumen than HS cows, even if the same diet was fed, potentially resulting in lower microbial protein synthesis (Nocek and Russell, 1988) and more N secretion via MUN. Schlau et al. (2012) showed that acidosisresistant steers had higher ruminal $\mathrm{pH}$ and lower VFA concentration compared with cows prone to SARA. However, we used mid-lactation cows in the current rumen pH-monitoring study, and MUN concentration did not differ between LS and HS cows (11.8 vs. 10.9 $\mathrm{mg} / \mathrm{dL}$, respectively; $P=0.56$ ). Rumen $\mathrm{pH}$ is expected to be generally lower for mid-lactation cows than latelactation cows due to greater DMI. Although we used a different set of animals, mean rumen $\mathrm{pH}$ was 6.47 for LS cows in the previous study that used late-lactation cows (Gao and Oba, 2014) whereas mean rumen $\mathrm{pH}$ of LS cows was 6.35 in the current rumen $\mathrm{pH}$ monitoring study, where mid-lactation cows were used. Abdoun et al. (2010) found that urea transport rates increased as mucosal pH decreased from 7.0 to 6.2. Therefore, lower rumen $\mathrm{pH}$ for LS cows used in the current rumen $\mathrm{pH}-$ monitoring study compared with the screening study might have increased urea recycling to the rumen and then decreased the amount of urea excreted in urine or milk, reducing the difference in MUN concentration between LS and HS cows and making it undetectable with statistical significance. Further research is warranted to explain why differences in MUN concentration between LS and HS cows were not consistent for different stage of lactation.

In conclusion, results from our study suggest that MUN and milk fat content in late-lactating cows fed a high-grain diet may be used to identify cows that have higher or lower risk of SARA. However, further research using a greater number of animals is warranted. In addition, it is necessary to determine whether differences in MUN concentration between LS and HS cows are affected by stage of lactation.

\section{ACKNOWLEDGMENTS}

The authors acknowledge the financial support of Alberta Milk (Edmonton, AB, Canada) and Natural Sciences and Engineering Research Council of Canada (Ottawa, ON, Canada). The authors also thank the Dairy Research and Technology Centre staff for general animal husbandry, and Y. Sun, J. Haisan, S. Espinoza, 
and A. Ruiz-Sanchez (University of Alberta, Edmonton, AB, Canada) for their technical assistance.

\section{REFERENCES}

Abdoun, K., F. Stumpff, and H. Martens. 2006. Ammonia and urea transport across the rumen epithelium: A review. Anim. Health Res. Rev. 7:43-59.

Abdoun, K., F. Stumpff, I. Rabbani, and H. Martens. 2010. Modulation of urea transport across sheep rumen epithelium in vitro by SCFA and CO2. Am. J. Physiol. Gastrointest. Liver Physiol. 298:G190-G202.

AOAC International. 2002. Official Methods of Analysis. 17th ed. AOAC Int., Gaithersburg, MD.

Bauman, D. E., and J. M. Griinari. 2003. Nutritional regulation of milk fat synthesis. Annu. Rev. Nutr. 23:203-227.

Broderick, G. A., and M. K. Clayton. 1997. A statistical evaluation of animal and nutritional factors influencing concentrations of milk urea nitrogen. J. Dairy Sci. 80:2964-2971.

Brown, M. S., C. Krehbiel, M. Galyean, M. Remmenga, J. Peters, B. Hibbard, J. Robinson, and W. Moseley. 2000. Evaluation of models of acute and subacute acidosis on dry matter intake, ruminal fermentation, blood chemistry, and endocrine profiles of beef steers. J. Anim. Sci. 78:3155-3168.

Carlsson, J., J. Bergstrom, and B. Pehrson. 1995. Variations with breed, age, season, yield, stage of lactation, and herd in the concentration of urea in bulk milk and individual cow's milk. Acta Vet. Scand. 36:245-254

Carlsson, J., and B. Pehrson. 1994. The influence of the dietary balance between energy and protein on milk urea concentration. Experimental trials assessed by two different protein evaluation systems. Acta Vet. Scand. 35:193-205.

Cyriac, J., A. G. Rius, M. L. McGilliard, R. E. Pearson, B. J. Bequette, and M. D. Hanigan. 2008. Lactation performance of midlactation dairy cows fed ruminally degradable protein at concentrations lower than national research council recommendations. J. Dairy Sci. 91:4704-4713.

Dohme, F., T. J. DeVries, and K. A. Beauchemin. 2008. Repeated ruminal acidosis challenges in lactating dairy cows at high and low risk for developing acidosis: Ruminal pH. J. Dairy Sci. 91:35543567.

Gao, X., and M. Oba. 2014. Relationship of severity of subacute ruminal acidosis to rumen fermentation, chewing activities, sorting behavior, and milk production in lactating dairy cows fed a highgrain diet. J. Dairy Sci. 97:3006-3016.

Gustafsson, A. H., and D. L. Palmquist. 1993. Diurnal variation of rumen ammonia, serum urea, and milk urea in dairy cows at high and low yields. J. Dairy Sci. 76:475-484.
Hof, G., M. D. Vervoorn, P. L. Lenaers, and S. Tamminga. 1997. Milk urea nitrogen as a tool to monitor the protein nutrition of dairy cows. J. Dairy Sci. 80:3333-3340.

Kohn, R. A., K. F. Kalscheur, and E. Russek-Cohen. 2002. Evaluation of models to estimate urinary nitrogen and expected milk urea nitrogen. J. Dairy Sci. 85:227-233.

Nocek, J. E., and J. B. Russell. 1988. Protein and energy as an integrated system: Relationship of ruminal protein and carbohydrate availability to microbial synthesis and milk production. J. Dairy Sci. 71:2070-2107.

Oetzel, G. R. 2003. Subacute ruminal acidosis in dairy cattle. Adv Dairy Technol. 15:307-317.

Oetzel, G. R. 2007. Subacute ruminal acidosis in dairy herds: Physiology, pathophysiology, milk fat responses, and nutritional management. Preconvention Seminar 7A. Am. Assoc. Bovine Practitioners 40th Annual Conference, Vancouver, Canada. Am. Assoc. Bovine Pract., Auburn, AL.

Oltner, R., and H. Wiktorsson. 1983. Urea concentrations in milk and blood as influenced by feeding various amounts of protein and energy to dairy cows. Livest. Prod. Sci. 10:457-467.

Penner, G. B., J. R. Aschenbach, G. Gaebel, R. Rackwitz, and M. Oba. 2009. Epithelial capacity for apical uptake of short chain fatty acids is a key determinant for intraruminal $\mathrm{pH}$ and the susceptibility to subacute ruminal acidosis in sheep. J. Nutr. 139:1714-1720.

Penner, G. B., K. A. Beauchemin, and T. Mutsvangwa. 2006. An evaluation of the accuracy and precision of a stand-alone submersible continuous ruminal pH measurement system. J. Dairy Sci. 89:2132-2140.

Penner, G. B., K. A. Beauchemin, and T. Mutsvangwa. 2007. The severity of ruminal acidosis in primiparous Holstein cows during the periparturient period. J. Dairy Sci. 90:365-375.

Rius, A. G., M. L. McGilliard, C. A. Umberger, and M. D. Hanigan. 2010. Interactions of energy and predicted metabolizable protein in determining nitrogen efficiency in the lactating dairy cow. J. Dairy Sci. 93:2034-2043.

Roseler, D. K., J. D. Ferguson, C. J. Sniffen, and J. Herrema. 1993 Dietary protein degradability effects on plasma and milk urea nitrogen and milk nonprotein nitrogen in Holstein cows. J. Dairy Sci. 76:525-534.

Schlau, N., L. L. Guan, and M. Oba. 2012. The relationship between rumen acidosis resistance and expression of genes involved in regulation of intracellular $\mathrm{pH}$ and butyrate metabolism of ruminal epithelial cells in steers. J. Dairy Sci. 95:5866-5875.

Stone, W. C. 2004. Nutritional approaches to minimize subacute ruminal acidosis and laminitis in dairy cattle. J. Dairy Sci. 87:E13E26.

Wattiaux, M. A., E. V. Nordheim, and P. Crump. 2005. Statistical evaluation of factors and interactions affecting dairy herd improvement milk urea nitrogen in commercial Midwest dairy herds. J. Dairy Sci. 88:3020-3035. 